\title{
Tourism Area Potential Development Strategy through the Bottom up Planning Approach in Angsana District, Tanah Bumbu Regency
}

\author{
Catur Harianto , Ahmad Yunani, Muhammad Riduansyah Syafari, Andi Tenri Sompa
}

Masters in Development Administration, Postgraduate Program, Lambung Mangkurat University, J1. Brigjen H. Hasan Basri, Pangeran, Kec. Banjarmasin Utara, Kota Banjarmasin, Kalimantan Selatan 70123, Indonesia

\author{
DOI: $10.36348 /$ sjef.2020.v04i11.002 \\ | Received: 02.11.2020 | Accepted: 10.11.2020 | Published: 17.11.2020 \\ *Corresponding author: Catur Harianto
}

\section{Abstract}

This study aims to describe the strategy for developing the potential for tourism areas through a bottom up planning approach in the Angsana District, Tanah Bumbu Regency. A qualitative approach is used to collect and analyze data in the form of words and human actions regarding the strategy for developing the potential of the tourism area through the bottom up planning approach that has been obtained. The research informants consisted of the Youth, Sports and Tourism Office of Tanah Bumbu Regency, the Head of Angsana Village and village officials, and the Tourism Awareness Group (Pokdarwis). The data sources used are primary data and secondary data. Primary data is data obtained directly from informants at the research location. Secondary data in this study were obtained from notes, articles, internet and scientific writings related to the strategy to develop the potential for tourism areas through a bottom up planning approach in the Angsana district, Tanah Bumbu Regency. The data collection technique was carried out in three steps, namely: observation, interviews, and documentation. The results showed that the implementation of the development of the potential for tourism areas through the bottom up planning approach in the Angsana district, Tanah Bumbu Regency was still not effective. This can be seen from the uneven implementation of policies that have been made, because not all development programs have been implemented well. Apart from that, the limited infrastructure also creates separate obstacles such as the availability of toilets. The still low participation and creativity of the community in making the tourism sector one of the drivers of the regional economy and budget constraints both in villages and in the district and the absence of a master plan as a guideline in the long term are also constraining factors.

Keywords: Development strategy, bottom up planning, tourism.

Copyright $\odot 2020$ The Author(s): This is an open-access article distributed under the terms of the Creative Commons Attribution 4.0 International License (CC BY-NC 4.0) which permits unrestricted use, distribution, and reproduction in any medium for non-commercial use provided the original author and source are credited.

\section{INTRODUCTION}

Tanah Bumbu Regency is one of the regencies located in South Kalimantan Province which has a variety of tourism including natural tourism, historical heritage, religious tourism, and arts and cultural tourism. The location of Tanah Bumbu Regency is directly adjacent to the sea in the southern part so that there are beaches that have the potential as a natural marine tourism attraction which should be planned as a tourist destination. The development of the tourism sector has a strong influence on regional development in the area around tourism objects, because it can act as a major industrial sector, namely a leading sector that is able to improve the regional economy of Tanah Bumbu Regency so that it can compete with other regions, especially it can increase Original Local Government Revenue (PAD) and can improve the economy of the people, especially those in the tourist destination locations.
Tanah Bumbu Regency Government has tourism potential that is very potential to be developed, one of which is Angsana Beach. Angsana Beach is a beach located in Angsana Village, Angsana district, Tanah Bumbu Regency. Angsana Beach is located 192 $\mathrm{km}$ from the city of Banjarmasin and $76 \mathrm{~km}$ from Batulicin or downtown Tanah Bumbu Regency, approximately $7 \mathrm{~km}$ from Jalan Provinsi where road access to Angsana Beach is paved which makes it easy for visitors to get to these tourist sites. Its strategic location and not far from the center of the sub-district capital is a strength that is owned besides the beautiful panorama of nature and the sea. So it needs to get serious attention from the Provincial Government of South Kalimantan and Tanah Bumbu Regency to make Angsana Beach a tourist area that attracts tourists to come to Tanah Bumbu Regency. There are three focus forms of tourism that will be built in the Angsana Beach area, namely: beach tourism, coral reef tourism and 
mangrove tourism. This tourism development is expected to be able to increase the Original Local Government Revenue (PAD) of Tanah Bumbu Regency, Original Village Revenue (PADes) and the welfare of the community around the tourist area.

Tourism is a complex sector, involving classical industries, such as handicrafts and souvenirs, lodging and transportation businesses. A tourism object can be used as one of the attractive tourist objects if it is supported by the necessary facilities and infrastructure to support the development of tourism objects. Tourism infrastructure is all facilities that allow tourism facilities to live and develop so that they can provide services to satisfy the various needs of tourists.

The development of tourist destinations certainly requires a development strategy that is able to accelerate the development of tourism in these tourist sites. Development is a process of change for the better through well-planned efforts. The important meaning of development is progress/improvement, growth and diversification. Regional development has several development concepts as an effort to approach development through planning activities, namely Top down planning and Buttom Up Planning. Top down planning is a planning model carried out from superiors aimed at their subordinates where the boss is the boss, while the subordinate is only the implementer. In contrast to Top down planning, Buttom Up Planning is a plan that is made based on the needs, desires and problems faced, then subordinates together with their superiors determine policies or decision making and the supervisor functions as a facilitator. According to Alisyahbana [1] this approach is an effort to involve all parties from the start, so that every decision taken in planning is their joint decision and encourages full involvement and commitment to implement it.

Village development programs that are planned with a bottom up approach can always be accepted and receive support from community participation in their implementation in the form of donations of funds/materials and personnel. It can be interpreted that bottom up village development planning is effective in encouraging community participation in development in their village. As the results of research from Bryant and White [2] which suggest that the bottom up approach in village development planning is very effective because: (1) through a bottom up approach, the community can provide responses, answers or feed-back to the government regarding matters concerning answers, responses, reports, complaints, and others; (2) through a bottom up approach the community can express and channel their aspirations, requests or demands to the community; (3) through a bottom up approach bargaining, consensus or cooperation between the community and the government can take place; (4) through a bottom up approach an exchange process can occur between the public and the government. Therefore, an important implication of this study is that the village government must strive to implement a bottom up approach in development planning in the village. Pusic [3] states that development planning without paying attention to community participation will become planning on paper. Marzuki [4] states that there are two important features of a bottom-up (participatory) approach to village development, namely: (1) the existence of partnerships based on equality between the government and local communities which is manifested in the decision-making phase and implementation of program decisions; and (2) that local communities make their own decisions and take full responsibility for planning, implementing, monitoring and evaluating programs with government support. With regard to this explanation, the researcher then made an article based on the results of research on the strategy to develop the potential for tourism areas through the bottom up planning approach in the Angsana District, Tanah Bumbu Regency. The article is intended to provide a description of the strategy for developing the potential for tourism areas through a bottom up planning approach in the Angsana District, Tanah Bumbu Regency.

\section{RESEARCH METHODS}

This research uses a qualitative approach with descriptive methods. The findings of descriptive research are broader and more detailed than exploratory research. It is said more broadly because we examine not only the problem itself, but also other variables related to the problem. In more detail, because the variables are described on the factors. The location of this research is the tourism object of Angsana beach, Angsana Village, Angsana District, Tanah Bumbu Regency, South Kalimantan Province. The research location was chosen because Angsana beach tourism is one of the attractive tourist destinations because of the beauty of the beach tourism and coral reefs, so this has become a concern of the public both in the Tanah Bumbu Regency area and the South Kalimantan Province and even outside the island of Kalimantan.

The research subject is aimed at collecting data and information related to the strategy to develop the potential for tourism areas through bottom up planning approaches. The informants in this study were the Head of the Tourism Destination Division of the Youth Sports and Tourism Office of Tanah Bumbu Regency, the Village Head (Kades) of Angsana Village, the Head of the Angsana Village Welfare Section, and the Chairperson of the Angsana Village POKDARWIS. There are three steps of data collection, namely: 1) Observation by making framed observations, namely observations that have been compiled and the frameworks of what will be studied have been determined in advance. 2) Interview by collecting data to obtain information extracted from direct data sources through conversations or questions and answers to 
informants. Interviews in this qualitative research include in-depth interviews and gradual interviews. Indepth interviews were conducted in the context of participatory observation. 3) Documentation by collecting data on events that have passed. Documents can be in the form of writings, pictures, or monumental works by someone related to a strategy to develop the potential of a tourism area through a bottom up planning approach in the Angsana district, Tanah Bumbu Regency.

The data analysis technique used in this research is interactive analysis. This model has 4 components of analysis, namely: data collection, data reduction, data presentation, and drawing conclusions. Miles and Huberman's [5] model explains: 1) Data collection, namely collecting data at the research location by conducting observations, interviews, and documentation by determining data collection strategies that are deemed appropriate and to determine focus and data deepening in the subsequent data collection process; 2) Data reduction by selecting main things and focusing on important aspects so that the reduced data will provide a clearer picture; 3 ) Presentation of data in the form of narrative text; and 4) Conclusions in the form of concluding descriptions or descriptions of an object that was previously dim or dark so that after being examined it becomes clear.

The data triangulation stage is used as a data validation test technique by using something outside the data for examination purposes or as a source of comparison to existing data. Triangulation in credibility testing is defined as checking data from various sources in various ways, and at various times [6]. This research uses triangulation techniques and sources.

\section{RESEARCH RESULTS AND DISCUSSION}

Angsana Village is one of the villages in Angsana District, Tanah Bumbu Regency, which has an area of $64.87 \mathrm{Km}^{2}$ or $33.06 \%$ of the $196.55 \mathrm{Km}^{2}$ Angsana District. This village is $1 \mathrm{Km}$ from the capital city of Angsana District and $80 \mathrm{Km}$ from the capital of Tanah Bumbu Regency. Angsana Village consists of 7 RT and 2 Hamlet. Has a population of 2,296 people. The majority of Angsana villagers work as farmers/planters and fishermen. While others work as employees of private companies, Civil Servants, breeders, craftsmen, traders and others. One of the focuses of the vision and mission of Angsana Village is to improve economic development and Original Village Revenue (PADesa) through tourism. This is in line with the researcher's research topic. The various resources that exist in Angsana Village are certainly a separate asset for Angsana Village. However, this diversity cannot be implemented effectively if there are no offices or institutions that carry out and supervise it, especially issues of funding and licensing. So the need for village officials to collaborate with regional offices up to the district level and the need for synergy between village officials and community institutions such as tourism awareness groups (POKDARWIS) so that natural potential and tourism development can run well.

Referring to Article 6 contained in the Village Medium-Term Development Plan (RPJMDes) of Angsana Village, Angsana District, Tanah Bumbu Regency. So what is meant by a village development strategy is an effort to realize the village development program. The strategy in achieving village development is strategic action that is internal and external, namely: a) internal strategy in achieving village development programs including increasing the sources of Original Village Revenue (PADesa), encouraging increased selfreliance and community participation in every development, structuring. management of development planning through sorting out supra village and infrastructure development targets, as well as increasing critical awareness, routines and community political bargaining power in development management. b) external strategies in achieving village development programs include overseeing village development policies as outlined in the Village RPJM at musrenbang forums and OPD forums, building cooperation at the inter-village level to encourage local governments to implement policies in strengthening community empowerment-based development, encourage DPRD to be pro-people and form regional laws and regulations that support participatory development, encourage the function of DPRD (Regional House of Representatives) in local electoral districts as people's representatives in accommodating the aspirations of the Village RPJM, and build partnerships with third parties in realizing program achievements.

The internal and external strategies are expected to be able to achieve program indicators for the next 6 years, where each year will be evaluated in stages by considering problems and emergency conditions in each fiscal year. The form of monitoring and evaluation that can be applied later can be in the form of joint monitoring by the community and BPD (Village's Consultative Agency), accountability deliberations by each institution based on the program and implementation, evaluation and accountability deliberations for achievements, and RPJMDesa activities are carried out regularly every year along with the Musrenbangdes, as well as reports Village Head Accountability Statement Reports (LKPJ) at the end of each fiscal year. Development in Angsana Village is directed at efforts to develop growth centers to encourage sustainable rural development that has social, economic and ecological resilience as well as promote rural-urban linkages. This development policy is carried out with several strategies, namely implementing village governance, implementing village development, strengthening BUMDesa (Village Owned Enterprises) capital, community development, and empowering village communities. As for the strategic development issues in Angsana Village, which is surrounded by 
coastal beaches and mangrove forests, including: 1) development of downstream industries for oil palm and rubber plantation activities; 2) development of coral reef marine tourism as a mainstay tourism icon of the district; 3) development of marine and fishery product processing industries/centers; 4) local scale trade and service center. In addition, regional infrastructure, which is the connection between regions, especially to tourist objects, has problems such as axle roads and environmental roads that need to be improved, the condition of the river that has not been stable in flow causes a high risk of flooding or inundation, and still lack of drainage.

According to Law Number 23 of 2014 concerning Regional Government and Law Number 25 of 2004 (National Development Planning System), regional planning must be carried out in a participatory manner and originate from below (bottom up planning), which starts from the village. Realizing participatory regional planning requires a forum as a forum for residents or village officials. The Village Development Planning Deliberation (Musrenbangdes) is an annual stakeholder consultation forum to agree on the Village Development Work Plan (RKPDes) for the planned fiscal year. The ideal Musrebandes is a village meeting that is able to capture the overall needs of the village community, village potential, human resources and village progress. Before the village musrenbang is held, it should be preceded by the implementation of the hamlet meeting or musdus. The aims and objectives of the musdus are carried out in order to accommodate the aspirations and proposals of activities from the hamlet community. Then the results of the selection of activity proposals from each hamlet were collected and formulated by the formulating team to be brought to the musrenbangdes.

Furthermore, the proposed activities are included in the Village Development Work Plan (RKP Desa). All proposals from the hamlet community should be observed and made a priority ranking, this is because not all suggestions from the community can be accommodated in one budget year. After the RKPDes is compiled and mutually agreed upon in village meetings, then the village head determines it through a Village Head Decree (SK). The Village RKP that has been determined becomes a guideline in the preparation of the Village Budget (APBDes) document.

This activity is carried out in Angsana Village every year in formulating development plans. Related to development planning in the field of tourism development in this forum, of course, it starts. So that what is the priority need for the tourism development of Angsana Beach can be accommodated in this musrenbangdes. Suryono (2001) states that the bottomup concept of development can be realized by developing several principles.
The first principle is the principle at the village level. The principle at the village level can be carried out by formulating the problems faced by the community itself as input in the village development planning process and the introduction of the potential that the community has. Furthermore, the second principle is the principle at the sub-district level which can be done by making an inventory of the positive things that are felt, deepening or adding to the list of problems faced after understanding the positive things, determining actions and implementing actors for problem handling, and setting own priorities. Then the third principle is the principle at the district level which can be carried out by all participants listening to the presentation of proposals from the community, the community listening to and criticizing the programs of each Dinas which are presented what are the objectives and benefits in the development of the Angsana beach area. Furthermore, formulating actions for handling each community suggestion can be done through proposals that can be handled by the community themselves, proposals that require assistance from the government, and proposals that will be handled by the government. Finally, bottom up development planning, bottom up planning is considered a planning approach that should be followed because it is seen as based more on real needs.

Based on the data obtained by the Performance of the Tourism Awareness Group (POKDARWIS) with the Angsana Village Apparatus, the Youth Sports and Tourism Office of Tanah Bumbu Regency in the Development and Management of Angsana Beach, it focuses on three indicators, namely Responsiveness, Effectiveness and Accountability in carrying out tourism development on Angsana Beach.

\section{Responsiveness}

The attitude taken by POKDARWIS which only accommodates complaints is of course still lacking. POKDARWIS is also expected to think of solutions to visitors' complaints so that these problems can be resolved. The habit of throwing garbage out of place has become an obstacle in itself for POKDARWIS which has been difficult to resolve since the establishment of POKDARWIS in 2012 until now. Even though the availability of trash cans is sufficient.

\section{Effectiveness}

Effectiveness can be used as an indicator to assess whether the performance of the organization, in this case the Tourism Awareness Group (POKDARWIS) and the village apparatus of Angsana for the development and development of tourist areas, in developing and managing Angsana Beach has been going well or badly. Effectiveness is measured based on the achievement of targets set by the organization. Village officials in carrying out the development and management of the Angsana Beach tourist area have the responsibility of developing and improving the tourism 
sector by carrying out various activities. One of the activities aimed at developing Angsana Beach is by holding outreach and events. One of the programs or activities carried out is developing arts and culture as a promotional effort at every event held. Apart from promotion through visitors, promotion is also carried out through brochures, leaflets or tourism profile books for Tanah Bumbu Regency as well as electronic media such as television and the internet. Website media are also designated for national and even international promotion. Holding cultural activities on the Angsana beach can also be a medium for introducing local culture to future generations such as holding festivals for umbrellas, baayun, panting and others which can later be held at the tourist area of Angsana Beach, Tanah Bumbu Regency.

Some of the programs or activities carried out at Angsana Beach are already running properly. However, there are still several development programs that have not been realized, such as the provision of telecommunication network transmitters that have not been implemented until now. In addition, the pandemic has also hampered various development plans due to funding cuts. The lack of adequate space provided such as a leaked payday and home stay, as well as the inadequate availability of toilets have also become homework for POKDARWIS and Angsana village officials to build and develop the Angsana beach tourism area.

\section{Accountability}

Accountability in the development and management of Angsana Beach by the Tourism Awareness Group (POKDARWIS), Angsana Village Officials and the Youth Sports and Tourism Office of Tanah Bumbu Regency in this study shows how much the level of conformity between the programs or activities of POKDARWIS tourism areas and those who have authority. The accountability of POKDARWIS in the tourist area of Angsana Beach can be defined as a form of accountability for activities or programs and management of existing facilities and infrastructure on Angsana Beach to those who have the authority to hold this accountable. The accountability of the Tourism Awareness Group (POKDARWIS) and village officials in the development of the Angsana Beach Tourism Area in the development and management of Angsana Beach still has several obstacles, namely communication with various parties who are deemed insufficient to improve so that it has a good impact in the future. In addition, the POKDARWIS of the Angsana Beach tourist area did not anticipate the effects of the programs or activities they made, they only thought about the impact after the program was completed. Even though in Angsana District there are mangrove forests and other coastal areas that can be used as tourist objects, but the local government has not included it in the main priority program, plus in 2020 the Covid-19 pandemic has hit the tourism sector which makes the task of local governments in developing tourism objects even harder in the future.

\section{CONCLUSION}

Based on the results of the research and discussion that has been presented, it can be concluded that the implementation of the development of Angsana Beach based on the concept of bottom up development or development from the bottom up, is still ineffective because several programs are not implemented. As for the bottom up development aspects at Angsana Beach which have been formulated in the development program, including physical and non-physical developments, including the construction of coastal facilities and infrastructure, such as roads, bridges, housing and so on, the implementation is still not optimal.

The strategy to develop the potential for tourism areas through a bottom up planning approach in the Angsana District, Tanah Bumbu Regency, which is carried out is: 1) Implementing the Musrenbangdes by involving elements or elements of the community consisting of BPD, Head of Hamlet, RT (neighbourhood chief), LPM (Community Empowerment Board), Pokdarwis and other institutional elements; 2) Formulation of development priorities in the tourism sector; 3) Organizing socialization/promotion and events; 4) Forming and optimizing the Tourism Awareness Group (Pokdarwis); 5) Making a Master Plan.

The factors that become obstacles to the strategy for developing the potential for tourism areas through the bottom up planning approach in Angsana District, Tanah Bumbu Regency, namely the low participation and creativity of the community to make the tourism sector one of the drivers of the regional economy, budget constraints both in the village and in the Regency there is a master plan as a guide in the long term.

\section{REFERENCES}

1. Alisyahbana. (2003). Pembangunan dari tingkat bawah ke atas. Yogyakarta: Gajah Mada University Press.

2. Bryant, C., \& dan White, L. (1985). Manajemen Pembangunan untuk Negara-Negara Berkembang. Jakarta: LP3ES.

3. Adi, I. R. (2001). Pemberdayaan Pengembangan Masyarakat dan Intervensi Komunitas. Jakarta: Fakultas Ekonomi UI, cet. ke-1.

4. Marzuki, M. (2004). Pendekatan dan Proses Pembangunan Partisipatif, Modul PKM. Jakarta: Departemen Dalam Negeri.

5. Milles, M. B., \& dan Hubberman, A. M. (2014). Analisis Data Kualitatif, Terjemahan oleh Tjetjep Rohidi dan mulyarto. Jakarta: UI Percetakan.

6. Sugiyono. (2009). Metode Penelitian Bisnis (Pendekatan Kuantitatif, Kualitatif dan R\&D). Bandung: Alfabeta. 